DOI: 10.1515 /auseur-2015-0005

\title{
Calvary of the Germans in Hungary at the end of WWII
}

\author{
Eleonóra MATKOVITS-KRETZ \\ National Circle from Pécs-Baranya of the Germans of Hungary
}

\begin{abstract}
The German community in Hungary suffered many blows at the end of World War II and after it, on the basis of collective guilt. Immediately after the Red Army had marched in, gathering and deportation started into the camps of the Soviet Union, primarily into forced-labour camps in Donetsk, the Caucasus, and the Ural mountains. One third of them never returned. Those left behind had to face forced resettlement, the confiscation of their properties, and other ordeals. Their history was a taboo subject until the change of the political system in 1989. Not even until our days, by the $70^{\text {th }}$ anniversary of the events, has their story reached a worthy place in national and international remembrance. International collaboration, the establishment of a research institute is needed to set to rights in history the story of the ordeal of the German community after World War II, for the present and future generations.
\end{abstract}

Keywords: Malenkey robot, Soviet lager, deportation, labour camp, prisoners of war, relocation, collective guilt, Swabian Holocaust, Germans from Hungary, forced migration

\section{Mission of the Association Pécs-Baranya Ethnic Circle of Germans in Hungary}

Our association was founded in 1991. Its main aim is the representation of interests and the research of the true history of the German national minorities. The Circle has been intensively involved in researching the Malenkij Robot since 2008. Thanks to EU applications, we have had the chance to travel to the Donets Basin and to the Ural mountains, where we got to visit such lagers where the civilian population was deported following WWII from the Carpathian Basin because of their German or Hungarian origin. We could not find the barracks, but we found many of the nearby graves. A DVD film was made on our travels. We have also published books on the topic; Malenkij Robot - 'Our only sin was our origin' and 'I was in captivity far in Russia'. We commemorate those transported to the Malenkij Robot every year in the framework of a conference, exhibition, 
or presentations. We make interviews with those still alive by involving young people. Our first partner organization from outside of our borders was the Historical Memorial Park of Szolyva Committee represented by György Dupka writer, poet, and researcher. By now, we have partner organizations from Transylvania, Vojvodina, Upper Hungary, Slovakia, the Czech Republic, and Poland. Our aim is to have the tragic story of those civilians deported to the Soviet Union become part of international memory and be part of our history books in Europe.

\section{Germans: 1,000 years in the Carpathian Basin}

A quotation from the study of Ágoston Keisz about the history of Germans in Hungary: the history of Hungary and the Germans has been intertwined for about 1,000 years. In our common history, we characteristically used to live together in peace. Germans in the country have lived without any serious conflicts with all the other nations. The first Germans arrived to Hungary already in the Middle Ages. Saxons used to settle in Transylvania and in the northern parts of the area that is Slovakia today. They were mainly city dwellers; the birth of the Hungarian cities and trade is mainly attached to them. The second big wave of colonization took place in the second half of the $18^{\text {th }}$ century. Following the decrease of population as the result of the Turkish wars, first it was the Hungarian lords and then the Viennese court that initiated colonization attempts. Those German groups who arrived in Hungary at those times mainly settled around Pest-Buda, in Fejér, Veszprém, Somogy, Baranya and Tolna counties, between the Danube and Tisza rivers, and some other places.

By the turn of the $19^{\text {th }}$ and $20^{\text {th }}$ centuries, the German population had an important role in the life of the country. Looking at their numbers, in the year 1910, about $10 \%$ of the population was made up of Saxon and German minorities. They had essential roles in the civilian transition and in the industrial and mining processes. They established a flourishing agricultural economy.

After the Treaty of Trianon had downsized the country, the circa half a million members of German minority mainly living off the land and working in agriculture became the greatest minority, giving about $6-7 \%$ of the full population. 


\section{Conflicts regarding the Germans in Hungary in the 1930s}

Here are some of the reasons:

Hitler gaining power: the national socialist politics found some supporters among the Hungarian Germans too. Volksbund was founded in 1938, but it only got under Nazi rule by 1944 .

Anti-German movements became stronger as their ideas were consciously spread in the country. Since the financial situation of the Germans was way better than that of the Hungarians, popular belief had it that if they were to be driven out of the country the lands they used would fulfil the poor Hungarian peasants' need for land, and later, in the framework of the population exchange programme, the empty houses would serve as home for the newcomers. And this idea was shared by leading politicians as well.

Their wealth that was to be confiscated would help to solve the catastrophic social situation following the war.

They became the culprit for the loss suffered during WWII.

By the end of WWII, the coming of the Red Army and the actual international atmosphere was a good ground for driving the Germans out of the country - just by the principle of collective guilt. This was primarily stressed by the Communist Party and the National Peasant Party.

\section{Impacts on the German Minorities before and after WWII}

The 13 most serious impacts:

1. Police abuse and harassment became frequent.

2. The internment camps established for the political criminals were mainly filled by Germans, and they were the majority to be obligated to do public labour or carry out forced labour.

3. During the forced enrolment processes of the German army (to the SS or the Wehrmacht), mainly German-born people were transported. 'Take the Germans' was a common viewpoint in Hungary.

4. Truculence from the incoming Red Army was an everyday issue in the occupied villages. Houses, cellars, and families were robbed, food reserves taken away, and women raped. Murder was also quite common.

5. 15 March 1945 marks the birth of the regulation of the Provisional Government Land Reform, the $2^{\text {nd }}$ chapter of which states who can be deprived of their lands: the full land shall be taken away from traitors, far-right-wing leaders of the Nyilas or other national socialist and fascist groups, members of the Volksbund and war criminals. In reality, it was the Germans who were deprived of their full wealth if others needed it. In the villages, land claimant committees were formed. 
6. The pressure for the Hungarianization of names got stronger by 26 May 1945.

7. July 1945 marks the loss of citizenship (by the decision of the Potsdam Conference).

8. During the 4 November 1945 elections, the Germans got no right to vote if they had been voluntary members of the SS, right-wingers, interned, sentenced by the people's court or if they considered themselves German in 1941. (According to the 1941 census, the number and rate of Germans was the highest in Baranya County. Around $30 \%$ of the population considered themselves German. Not considering the central city Pécs, this number was rather $40 \%$.)

9. High number of war cripples; psychological and physical scars and injuries; prisoners of war and a high number of fallen or lost relatives.

10. Full deprivation of citizen rights for 5 years, relocations.

11. Political and cultural discrimination: prohibition of the use of mother tongue and education until the 1950s.

12. Relocation - driving people out of the country in the period of 1946-48.

The Potsdam Conference gave way to the relocation of the German population. The Temporary Hungarian Government was obliged to relocate 400-450 thousand Germans. Their lands and wealth were seized.

During the Potsdam Conference held in the second half of July in 1945, the representatives of the USA, GBR, and the former Soviet Union made the decision of relocating Germans from Hungary, the former Czechoslovakia, and Poland. This action affected those who served in the Hungarian army or were not even Volksbund members. (The majority of Germans in Baranya were mainly peasants living in the villages.) Only those people could get immunity who entered the communist party. But, as per the motto of the communist party, 'rich Swabians have no excuse' - even if they were innocent.

The first train left Budaőrs on 19 January 1946 and the last one in autumn 1948. A very large number of Germans were relocated from Baranya. There were such villages where two-thirds of the Germans were chased away, their houses, lands, and animals seized. Numerous villages were almost fully abandoned where Germans used to live in majority.

\section{Malenkij Robot:}

Transporting people to the Soviet lagers for a 'little work'. Kidnapping and abductions started by Order 0060 dated 22 December 1944, in Baranya County. The preceding central order, 7161, dated on 16 December 1944, was actually signed by none other than Stalin himself. This order dealt with the transportation of the Germans to the former Soviet Union for reparation works from the areas 'liberated' by the Red Army. The Order also stated that the internment processes should be carried out through the governmental organizations of the given country. (Order 0060 was dated on the same day when the Moscow-controlled Temporary Hungarian Government was established. It is possible that the intention was to 
address this way the responsibility of the German relocations in part or fully to the Hungarian Government.)

Baranya County was occupied by the $3^{\text {rd }}$ Ukrainian Front of the Red Army in November/December 1944. The order regarding the relocation of the Germans was signed by the regions around 22 December. The Hungarian authorities made a list of the people who were considered German by each village - whoever was on the list had to check in at the central office of their village. From there, they were sent to the Russian military headquarters set up in the district centres. This obligation concerned women between the ages of 18 and 30 and men between the ages of 17 and 45. They had to carry food and clothes for two weeks with themselves, allegedly to construct the Pécs Airport or to work on the Bácska corn fields. They learned about the fact that they were transported to Russia only at the train station - if they learned it at all. Other than the above mentioned people, that is children aged 14-15, elderly, senior citizens, and pregnant women, were deported too.

Around 5-6,000 thousand civilians were deported from around 200 villages from Baranya. The exact number remains unknown because in Baranya no single list was constructed like in Tolna County, for example. In many places, only such a list is available that includes the name of just those people in the cases of whom extraction was initiated. And this solely happened in the case of politically trustworthy persons. No people who considered themselves German during the census could get on the list. This is where the popular misbelief is rooted that from Baranya County only 700 persons from 69 villages were transported to the Malenkij Robot, because these people were those Hungarians who were earlier transported with the Germans by mistake.

Strangely enough, the full area of the county was affected by the Malenkij Robot even though there were hardly any Germans living in the southern and western parts. While from the German-populated regions mainly Germans were deported, from the other villages, people who had German-sounding names and German spouses were also taken. In some cases, they deported such demobilized soldiers who served after 1941, during the time when the former Soviet Union was attacked. From the villages, people were often driven on foot to the Pécs collection site, the Lakits army base in the middle of winter. From the village of Babarc, people were taken away on 22 December and, in some cases, on 23 and 24 December, the day of Christmas too. The collection date in many places was the second day of Christmas in 1944. The majority started their journey on 25 and 26 December. On the Hungarian side, the commands were usually executed by the Chief Constable of the county. The collection was carried out with military assistance.

The trains were assembled in the Pécs train station in the first half of January 1945, each car capable of carrying 40 people crowded together. They were transported along the route Baja - South Transylvania - Sibiu - Braşov Ploieşti - Iaşi or Oltenia - Timişoara - Lugoj - Caransebeş - Bucharest - Ploieşti 
to Jassy in utterly inhumane circumstances. Many had not made it alive to the destination. (Torda - Braşov and Focşani used to be the largest gathering lagers in Southeast Europe; about 50-60 thousand German and Hungarian prisoners of war languished here. Focşani also served as a transit station.) People changed to the broad-gauge Soviet trains in Iaşi. From here, the route went towards the Donets Basin or to the Caucasus, but the final destination could also be some different area of the former Soviet Union like parts of the Ural or Byelorussia.

\section{Malenkij Robot by the Place of Capture}

Most of the people, including Hungarians and Germans, were deported from Baranya, Tolna, Bács-Kiskun, Békés, Pest-Pilis-Solt-Kiskun, Borsod, SzabolcsSzatmár, and Zemplén counties.

Prisoners were decimated by the brutality of the prison guards, the given quotas, the terrible conditions, the daily 10-12 hours of hard and demanding work, hunger, sicknesses, and freezing temperatures.

The prisoners worked in mines, on the construction sites of roads, dams and railroads, laying crude oil pipelines, like that of the Druzhba pipeline (Bashkortostan), without appropriate tools, clothes or food, many times in as cold a weather as minus 30 degrees Celsius.

Prisoners also worked in the Donetsk Basin, the Ural or Caucasian industrial regions, or around greater cities at the construction sites or renovation works of water plants. There was not one international convention dealing with their cases, not even the Red Cross visited them. It was the sole decision of the former Soviet Union when they would let the prisoners go.

\section{Returning Home}

On 9 May 1945, when the war was already over, many people hoped they could return home. In fact, some civilians did return among the prisoners of war on special ambulance trains.

I. $\quad$ 1946. 38 trains

16,322 prisoners of war

II. 1947. 89 trains

101,623 prisoners of war

III. 1948. 68 trains

88,325 prisoners of war

IV. 1949.

5,055 prisoners of war (Germans in majority)

The POW - prisoner of war name includes the civilians too; they were not separated.

Debrecen: This city used to have a POW care camp where they received a certificate of their medical examinations, 20 Forints in cash, and a handkerchief. 


\section{Remembrance}

'Our Russian supervisor accompanied us all the way to Debrecen, where he handed us over. We had a wash and they took us home. Here they already knew whose whole family was transported to Germany. They did not have to come home to Nádasd; they were transported straight to Germany.'

'By the time I got home, my parents had already been in Germany. I could not go back to our own house, we were thrown out. Everything was taken away from us, we had nothing left. I ended up in an empty house from where another family had been taken away and had left everything behind.' (89-year-old Aunt Marika; Ferencné Reisz from Mecseknádasd, from the interview conducted by Zsuzsanna Elblinger in February 2014.)

The exact number of people deported to the lagers in the former Soviet Union requires further investigation because there is too much controversial data available right now. According to some estimates, around 360 thousand civilian and 600 thousand prisoners of war were the victims.

Where can the numbers be found?

- the local Red Cross office might hold the list of deported civilians in the municipalities like in Pécsvárad;

- in parish churches if the documents have not been seized earlier from the parish priest

- the District National Committees also had a role in listing and classifying the names;

- in the material of the County National Committee in Pécs (They actually called the attention of the Soviets to the fact that 'the Germans are Hungarian citizens'. The Soviet answer was that 'we do not modify the order'.).

Deportation, internment, ethnicity-based collective punishment and genocide, labour camps, death camps - shall these words be used in connection to the crimes committed against Germans and Hungarians in the Carpathian basin? Yes, because in their case all of these were present.

\section{International Background}

The deportation of several thousand Germans to labour camps took place with the collective agreement of the allied forces following Stalin's order on 16 December 1944.

During the Tehran Conference between 28 November and 1 December 1943, Stalin already stated to the allies that he wished to use the work force of 4 million Germans in the reconstruction period for a few years. 
The deportation of Germans to the former Soviet Union for reparation works regarding the damage they caused was part of the German compensation - as written in a telegram by President Roosevelt of the United States on 18 January 1945.

According to Winston Churchill, Prime Minister of Great Britain, during the war, Russia suffered a lot of damage; so, they are not to be blamed if they requested 100 or 150 thousand people of any origin from, for example, Romania to work in their mines (note from 19 January 1945).

Stalin has made his final decision backed up by the cynical approach and ignorance of the allied forces. 'The gathering and internment of the Germans shall be realized between December 1944 and January 1945, and their transportation to the work locations shall be finished by 15 February 1945.'

The $70^{\text {th }}$ anniversary gives a great occasion to call attention to the stories of those deported to Soviet lagers and the tragic happenings that are kept secret while teaching history. The guilty shall be named and those responsible brought to light during the Memorial Day. The English and American allies, as they did with many similar cases like the Katyn murder of 22 thousand Polish soldiers, overlooked the enslavement of several thousand East European (like Hungarian) prisoners of war and forced workers, considering it as the reward of the Soviet allies for their military victories.

Those deported, withstanding the physical and psychic sufferings, loss and ordeals, have always kept their human dignity. Their faith has kept them. Their deep religiousness gave them will and fortitude. German and Hungarian prayers and songs were born in the captivity, where victims told their misery to God and asked for redemption.

They are role models for their descendants. Their spiritual magnitude is proved by the fact that they have no lust for vengeance in their hearts. They also feel gratitude for those Russians who gave them food and helped them.

We, successors, have the obligation to keep the memory of the innocent victims and commemorate them in every possible way: by organizing conferences, international memorial years, through research institutions, by establishing a full database of the names with those who did not survive, through the old lager locations and burial sites. Documentaries, thematic radio programmes, scientific and literary volumes, memorial sites, memorial plaques, memorial journeys to the gathering, spreading lagers, and that of the former Soviet Union should be made, published, or organized.

14. Those returning from the labour camps were treated with discrimination. They did not get any, or did not get proper work. They had everyday existential problems. They were deprived of their rights. They did not get any certificate about the fact that they were imprisoned in lagers. No indemnity or military compensation was given to them. 


\section{The Obligations of the Descendants}

The future generations shall inherit the knowledge not just through national school education but in the European education systems as well (for example, in the framework of an EU project, the common European history books could be expanded with a chapter about the stories of those transported to the lagers of the former Soviet Union).

The tragedy of the Malenkij Robot shall become part of international and national memories.

\section{References}

BOGNÁR Zalán. 2011. Malenkij Robot „Egyetlen bûnünk a származásunk volt.” Német és magyar polgári lakosok deportálása „Málenkij Robot”-ra a Sztálini lágerekbe 1944/45-1955 (Malenkaya Rabota "Their only one guilt was their origin.' Deportation of German and Hungarian civilians to 'Malenkaya Rabota' in Stalins' lagers 1944/45-55). Pécs: Magyarországi Németek Pécs-Baranyai Nemzetiségi Köre.

FRIESZ Péter. 2010. A német kisebbség Pécsváradon és környékén 1944-1948 (The German Minority in Pécsvárad and Its Surroundings 1944-1948). In: Gállos Orsolya (ed.), 2010. Orosz kényszermunkán. Pécsvárad és a környék német kisebbsége, 1944-1948 (On Russian Forced Labour. The German Minority of Pécsvárad and Its Surroundings, 1944-1948). Pécsvárad: Pécsváradi Füzetek 3. Pécsváradi Várbaráti Kör. pp. 9-94.

GÁLLOS Orsolya (ed.). 2010. Orosz kényszermunkán. Pécsvárad és a környék német kisebbsége, 1944-1948 (On Russian Forced Labour. The German Minority of Pécsvárad and Its Surroundings, 1944-1948). Pécsvárad: Pécsváradi Füzetek 3. Pécsváradi Várbaráti Kör.

GLASS, Christian. 2012. Migration im Donauraum. Die Ansiedlung der Deutschen im 18. Jahrhundert und ihre Folge. Ulm: Stiftung Donauschwäbisches Zentralmuseum.

GONDA Gábor. 2014. Kitaszítva. Kényszeremigráció, nemzetiségpolitika és földreform németek által lakott dél-és nyugat-dunántúli településeken 19441948 (Left Out. Forced Emigration, National Politics and Agrarian Reform in Settlements of Southern and Western Transdanubia Inhabited by Germans 1944-1948). Pécs: Kronosz Kiadó.

MOLNÁR Csaba. 2013. Migráció a Duna térségében. A németek betelepülése a 18. században (Migration in the Area of the Danube. The Settling of Germans in the $18^{\text {th }}$ Century). Pécs: Molnár Nyomda és Kiadó Kft. 